\title{
SISTEM INFORMASI PENJUALAN BERKONSEP PEMESANAN MANDIRI RM PERANG KERANG DEPOK
}

\author{
Rizkiana Hadi Saputra \\ Program Studi Teknik Informatika, Fakultas Teknik dan Ilmu Komputer, \\ Universitas Indraprasta PGRI \\ Jalan Raya Tengah No 80, Kelurahan Gedong, Pasar Rebo, Jakarta Timur \\ rizkianahadi18@gmail.com
}

\begin{abstract}
Abstrak
Zaman sekarang teknologi telah tumbuh sangat pesat, masyarakat pun membutuhkan teknologi untuk keperluan mereka, terlebih lagi untuk perusahaan. Teknologi yang diperlukaan saat ini adalah komputer. Maka dari itu, Rumah Makan Perang Kerang mempunyai permasalahan yaitu masih menggunakan cara manual dalam pemesanan menu untuk pelanggan. Tujuan penelitian ini adalah merancang sistem informasi penjualan berkonsep pemesanan mandiri untuk pelanggan yang dapat digunakan saat memesan menu di Rumah Makan Perang Kerang. Metode penelitian yang digunakan adalah metode Research \& Development, yaitu penelitian berdasarkan pengumpulan data, perencanaan, pengembangan produk dan desain, penyempurnaan produk, dan implementasi. Sistem informasi penjualan berkonsep pemesanan mandiri ini dibuat untuk menjadi lebih efektif dan efisien dalam memesan menu, informasi pesanan, penghitungan pembayaran, dan laporan - laporan yang diperlukan dalam Rumah Makan Perang Kerang. Sistem informasi ini dibuat menggunakan Software Netbeans dan database MySQL.
\end{abstract}

Kata Kunci: Penjualan Berkonsep Pemesanan Mandiri, Menu, Research \& Development, Netbeans, MySQL

\begin{abstract}
Nowadays technology has grown very rapidly, people also need technology for their needs, especially for companies. The technology needed today is a computer. Therefore, Rumah Makan Perang Kerang has a problem that is still using the manual method in ordering menus for customers. The purpose of this study is to design a sales information system with the concept of self-ordering for customers that can be used when ordering menus at Rumah Makan Perang Kerang. The research method used is the Research \& Development method, namely research based on data collection, planning, product development and design, product improvement, and implementation. This self-ordering concept sales information system was created to be more effective and efficient in ordering menus, order information, calculating payments, and reports needed in Rumah Makan Perang Kerang. This information system is made using Netbeans software and MySQL database.
\end{abstract}

Keyword: Self-designed Salse, Menu, Research \& Development, Netbeans, MySQL

\section{PENDAHULUAN}

Saat ini sarana komunikasi atau pertukaran informasi yang cepat dan mudah menjadi hal yang banyak dibutuhkan dan ditunjang oleh kemajuan teknologi yang semakin meningkat. Sesuai dengan perkembangan zaman, banyak sekali persaingan yang menyebabkan tiap - tiap perusahaan berusaha meningkatkan kinerjanya untuk mencapai hasil yang maksimal. Kondisi tersebut mengharuskan perusahaan mengubah sistem yang telah berjalan ke sistem yang baru sesuai dengan kemajuan teknologi saat ini untuk melanjutkan keberhasilan bisnis perusahaan. Saat ini Rumah Makan Perang Kerang masih menggunakan cara manual seperti menggunakan media alat tulis dan kertas untuk pemesanan menu makanan dan minuman. Ada beberapa kendala seperti memakan waktu yang lama, tidak terbacanya tulisan, terselipnya kertas catatan pemesanan, adanya pesanan yang rangkap, dan pesanan yang terlupa. Laporan penjualan pun masih menggunakan alat tulis dan belum otomatis.

Maka dari itu, untuk mengatasi masalah tersebut, peneliti membuat sistem pemesanan menu yang terkomputerisasi dan mudah untuk digunakan oleh para pelanggan, karyawan, dan pemilik Rumah Makan Perang Kerang. Pemesanan menu yang dapat dilakukan sendiri, barista dapat melihat pesanan yang dipesan secara terkomputerisasi, pembayaran pesanan yang dapat dilakukan secara mudah, rekap data sampai laporan - laporan yang diperlukan dapat dicetak dengan mudah. Sistem 
yang dibuat oleh peneliti berjudul "Perancangan Sistem Informasi Penjualan Berkonsep Pemesanan Mandiri pada Rumah Makan Perang Kerang Depok Berbasis Java".

Pada pembuatan sistem ini, peneliti menggunakan beberapa software yang diantaranya, Netbeans merupakan sebuah proyek kode terbuka yang sukses dan penggunaannya sangat luas, dengan komunitas yang terus tumbuh, dan terus bertambah (Huda, 2010). XAMPP merupakan paket software yang didalamnya sudah memuat Web Server Apache, Database MySQL, dan PHP Interpreter (Wardana, 2010). iReport merupakan perangkat lunak yang dapat membantu untuk perancangan laporan secara visual yang dikompilasi dengan JasperReport sehingga menjadi file jasper yang dapat dieksekusi oleh pemrograman Java (Riestiana, 2014). Peneliti juga menggunakan bahasa pemrograman yang diantaranya, Java merupakan bahasa pemrograman yang digunakan untuk menciptakan isi halaman web yang aktif, dan juga dapat dijalankan dalam semua komputer (Asropudin, 2013). Peneliti juga menggunakan Data Flow Diagram merupakan suatu network yang dapat menggambarkan suatu sistem yang otomatis atau terkomputerisasi, manualisasi atau gabungan dari keduanya (Tata Sutabri, 2012). Entity Relationship Diagram untuk merancang sebuah baris data, awalnya dengan mengidentifikasi data yang penting dan digambarkan dalam suatu model (Indrajani, 2015). Dan peneliti membahas tentang, Penjualan merupakan pendapatan yang dihasilkan dari penjualan produk perusahaan, disajikan setelah dikurangi potongan penjualan, dan retur penjualan (Sulistiyowati, 2010). Pemesanan merupakan kegiatan menerima dan mencatat pesanan tamu, yang selanjutnya akan diteruskan ke bagian terkait (Tegar, 2012).

\section{PENELITIAN RELEVAN}

Beberapa penelitian yang relevan dengan sistem informasi penjualan berkonsep pemesanan menu antara lain, penelitian yang dilakukan (Siahaan, dkk. 2018), dengan judul "Informasi Pemesanan Menu Dengan Perangkat Nirkabel Pada Cafe Resto". Latar belakang dari jurnal ini adalah para pelayan dituntut untuk bekerja dengan cepat melayani pemesanan pelanggan dan mengantarkan kepada pelanggan, akibatnya para pelayan terkadang hilang konsentrasi kerja yang mengakibatkan timbul kesalahan, seperti salah mengantarkan pesanan makanan ke meja pelanggan akibat tertukar menu pesanan, pencatatan menu masih manual, serta pesanan makanan yang lupa untuk disajikan. Rumusan masalah dari jurnal ini adalah cara menganalisis dan merancang sistem informasi pemesanan menu dengan perangkat nirkabel pada Cafe Resto Lucck Eat. Tujuan penelitian dari jurnal ini adalah agar sistem informasi pemesanan menu yang dibuat untuk restoran sudah terkomputerisasi dan bisa diakses dengan mudah. Dengan metode penelitian yang dipakai adalah melalui tahapan - tahapan seperti identifikasi masalah, studi literatur, pengumpulan data, analisis sistem, dan pembuatan laporan. Hasil pembahasan pada jurnal ini adalah penelitian bertujuan untuk merancang suatu aplikasi pemesanan menu makanan pada Cafe Resto Lucck Eat. Hasilnya, sistem informasi pemesanan menu ini dapat digunakan pada pelanggan untuk memilih menu yang diinginkan, bagian dapur juga dapat melihat pesanan yang dipilih oleh pelanggan, serta data pesanan yang sudah dibuat pesanannya oleh bagian dapur, dapat dilihat oleh kasir untuk menghitung biaya pesanan pelanggan.

Penelitian yang dilakukan (Tompoh, dkk. 2016), dengan judul "Rancang Bangun Aplikasi Pemesanan Menu Makanan Restoran Berbasis Android". Latar belakang dari jurnal ini adalah pemesanan menu saat ini sangat tidak efisien dan berantakan, karena sangat memakan waktu yang lama, tidak teratur saat antri, pelayan yang sangat sibuk dengan pelanggan lain, dan aturan yang rumit saat memesan menu. Rumusan masalah pada jurnal ini adalah bagaimana cara untuk merancang dan membangun aplikasi pemesanan menu makanan Taipan Resto Manado berbasis android dan dapat menggunakan web-service. Tujuan penelitian dari jurnal ini adalah agar aplikasi pemesanan menu yang dibuat untuk Taipan Resto Manado sudah terkomputerisasi dan bisa diakses dengan mudah dengan berbasis android dan dapat menggunakan web-service. Dengan metode penelitian yang dipakai adalah Rapid Application Development (RAD) yang merupakan metode pengembangan suatu sistem informasi dengan wktu yang relatif singkat. Dengan langkah - langkah yang dibagi dalam empat fase, yaitu analisa persyaratan, analisis modelling, desain modelling, dan konstruksi. Hasil pembahasan pada jurnal ini adalah penelitian bertujuan untuk merancang dan membangun suatu aplikasi pemesanan menu makanan Taipan Resto Manado. Hasilnya, aplikasi pemesanan menu Taipan Resto Manado diimplementasikan pada smartphone berplatform android dan personal computer untuk membantu pegawai dalam menangani pemesanan menu makanan. 
Penelitian yang dilakukan (Aswari, dkk. 2020), dengan judul "Rancangan Aplikasi Elektronik Menu Restoran PJ83 Jakarta Berbasis Android". Latar belakang dari jurnal ini adalah pemesanan menu yang terdapat pada Restoran PJ83 masih menggunakan cara manual seperti harus menulis terlebih dahulu menu pesanan yang akan dipesan. Rumusan masalah dari jurnal ini adalah cara membuat aplikasi elektronik untuk sistem pemesanan menu yang ada di restoran, yang dapat menggantikan sistem pemesanan lama ke sistem pemesanan baru yang dapat mempermudah pemesanan untuk pelanggan. Tujuan penelitian dari jurnal ini adalah agar memudahkan proses kerja yang berada di restoran, karena pelanggan dapat melihat langsung menu tanpa harus datang ke restoran. Dengan metode penelitian yang dipakai adalah menggunakan metode Grounded Research yaitu suatu metode penelitian yang berdasarkan fakta, menetapkan konsep, membuktikan dan mengembangkan adanya teori, dan analisis data. Hasil pembahasan pada jurnal ini adalah penelitian bertujuan untuk merancang dan membangung aplikasi elektronik pada Restoran PJ83. Hasilnya, aplikasi yang dibuat dapat memudahkan pelanggan untuk memesan menu secara cepat sebelum sampai ke tempat restoran. Ketika sampai di restoran, pelanggan dapat langsung menikmati hidangan menu yang telah disiapkan.

\section{METODE PENELITIAN}

\section{Desain Penelitian}

Dalam penelitian ini, peneliti menggunakan metode penelitian Research \& Development, yaitu:

a. Definisi Penelitian dan Pengembangan (Research \& Development)

Research \& Development merupakan metode penelitian yang digunakan untuk menghasilkan suatu produk tertentu, dan menguji keefektifan dari produk tersebut (Sugiyono, 2011).

b. Tahap - tahap Penelitian dan Pengembangan (Research \& Development)

1) Penelitian dan Pengumpulan Data

Sebagai untuk mengumpulkan informasi yang berkaitan dengan pembuatan produk.

2) Perencanaan

Berdasarkan studi pendahuluan yang telah dilakukan, bertujuan untuk target dari penggunaan produk, pengguna dari produk, dan deskripsi dari isi dan penggunaannya.

3) Pengembangan Produk

Sebagai draft kasar dari produk yang akan dibuat, draft tersebut harus disusun dengan lengkap dan sempurna mungkin.

4) Pengembangan Desain

Sebagai pembuatan desain untuk produk yang akan dibuat dan dikembangkan.

5) Penyempurnaan Produk

Sebagai untuk dilihat kembali produk yang dibuat, melihat ada kekurangan atau kelebihan dari produk yang dibuat. Jadi harus sesuai dengan keinginan dan keharusan.

6) Revisi atau Penyempurnaan Produk Akhir

Sebagai untuk mengubah, menghilangkan, atau menambahkan yang ada pada produk tersebut.

7) Diseminasi dan Implementasi

Sebagai untuk mempublikasikan hasil yang telah dibuat, dan dapat dikembangkan agar dapat diimplementasikan dari produk yang dibuat.

\section{Metode Pengumpulan Data}

Dalam penelitian ini, peneliti menggunakan metode pengumpulan data, yaitu :

a. Studi Literatur

1) Mempelajari sistem dari aplikasi pemesanan menu yang lainnya.

2) Mempelajari dari jurnal - jurnal tentang penjualan dan pemesanan.

b. Metode Lapangan

1) Observasi

Dilakukan dengan mendatangi langsung dan survey ke RM Perang Kerang secara langsung untuk mendapatkan informasi dasar yang dibutuhkan terhadap objek yang diteliti. Peneliti melakukan penelitian dan mempelajari tentang pemesanan menu, cara barista melihat pesanan, cara kasir menghitung pembayaran, dan laporan - laporan yang dibuat oleh pemilik. 
2) Wawancara

Peneliti melakukan wawancara langsung kepada karyawan yang bekerja sebagai barista mengenai pemesanan menu yang dilakukan pelanggan terhadap barista, kasir mengenai pengolahan data transaksi pembayaran, dan pemilik yaitu Bapak Suroto mengenai laporan - laporan yang diperlukan dalam usaha ini.

\section{Langkah - langkah Pengembangan Sistem}

Dalam penelitian ini, peniliti menggunakan langkah - langkah pengembangan sistem sebagai berikut :

a. Perancangan

Fase pertama dari pengembangan sistem ini. Pada fase ini membutuhkan sistem informasi dari suatu organisasi yang dapat diidentifikasi, dianalisa, dibuat prioritas, dan dapat disusun.

b. Analisis

Fase kedua dari pengembangan sistem ini. Pada fase ini sangat membutuhkan suatu sistem untuk mempelajari dan disusun untuk analisis sistem tersebut.

c. Desain

Fase ketiga dari pengembangan sistem ini. Pada fase ini mendeskripsikan solusi yang direkomendasikan dan dikembangkan ke dalam bentuk desain.

d. Implementasi

Fase keempat dari pengembangan sistem ini. Pada fase ini dibuat coding dari suatu sistem informasi yang telah di uji dan dapat digunakan sistemnya tersebut.

e. Perawatan

Fase terakhir dari pengembangan sistem ini. Pada fase ini dilakukan perawatan terhadap sistem yang telah dibangun, dan perawatan berupa back-up data dan pembuatan jadwal untuk pengoperasian sistem.

\section{HASIL DAN PEMBAHASAN}

Analisis Permasalahan

Setelah dianalisa, permasalahan yang ada pada sistem pemesanan menu yang berjalan di RM Perang Kerang, diantaranya :

1. Proses pemesanan menu yang masih menggunakan cara manual.

2. Ketika keadaan sedang ramai, pelanggan bergantian saat dilayani oleh barista.

3. Banyaknya tumpukan kertas dibagian barista, dan membutuhkan kertas daftar pesanan untuk menghitung pembayaran dibagian kasir.

\section{Alternatif Penyelesaian Masalah}

Setelah dianalisa dan mengevaluasi sistem yang sedang berjalan di RM Perang Kerang, maka alternatif penyelesaian masalah sebagai berikut :

1. Merancang sistem informasi penjualan berkonsep pemesanan mandiri yang terkomputerisasi.

2. Membuat aplikasi penjualan berkonsep pemesanan mandiri dengan Java, dapat mempermudah sistem pemesanan melalui media komputer tanpa harus menunggu dilayani oleh barista.

3. Semua data akan terkomputersasi. Jadi, tidak ada tumpukan kertas yang bertumpuk. 


\section{Diagram Konteks}

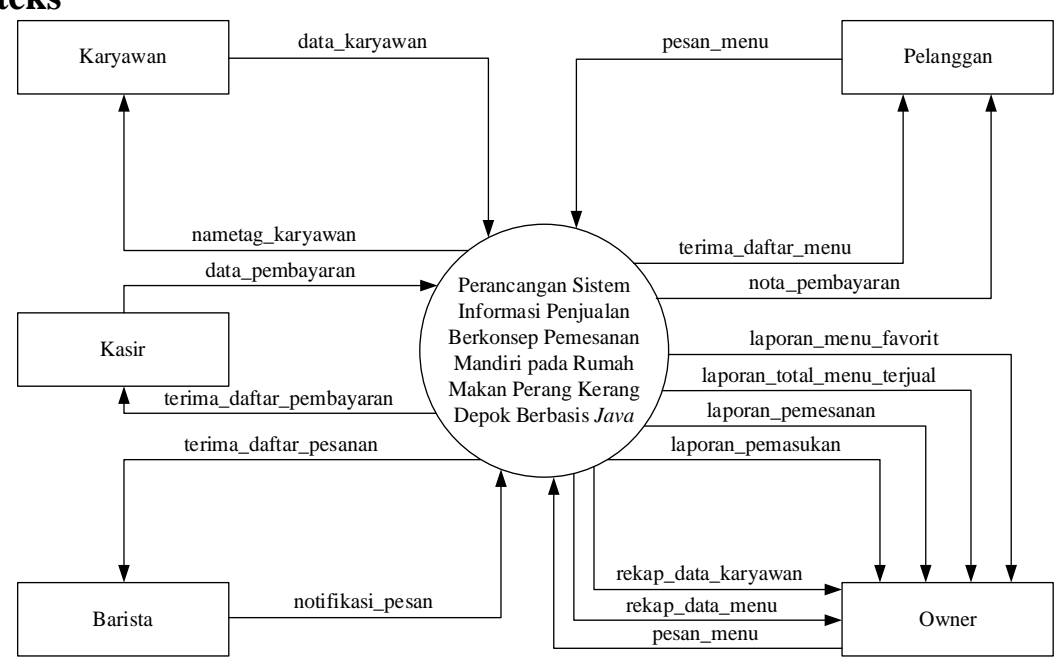

Gambar 1. Diagram Konteks

\section{Diagram Nol}

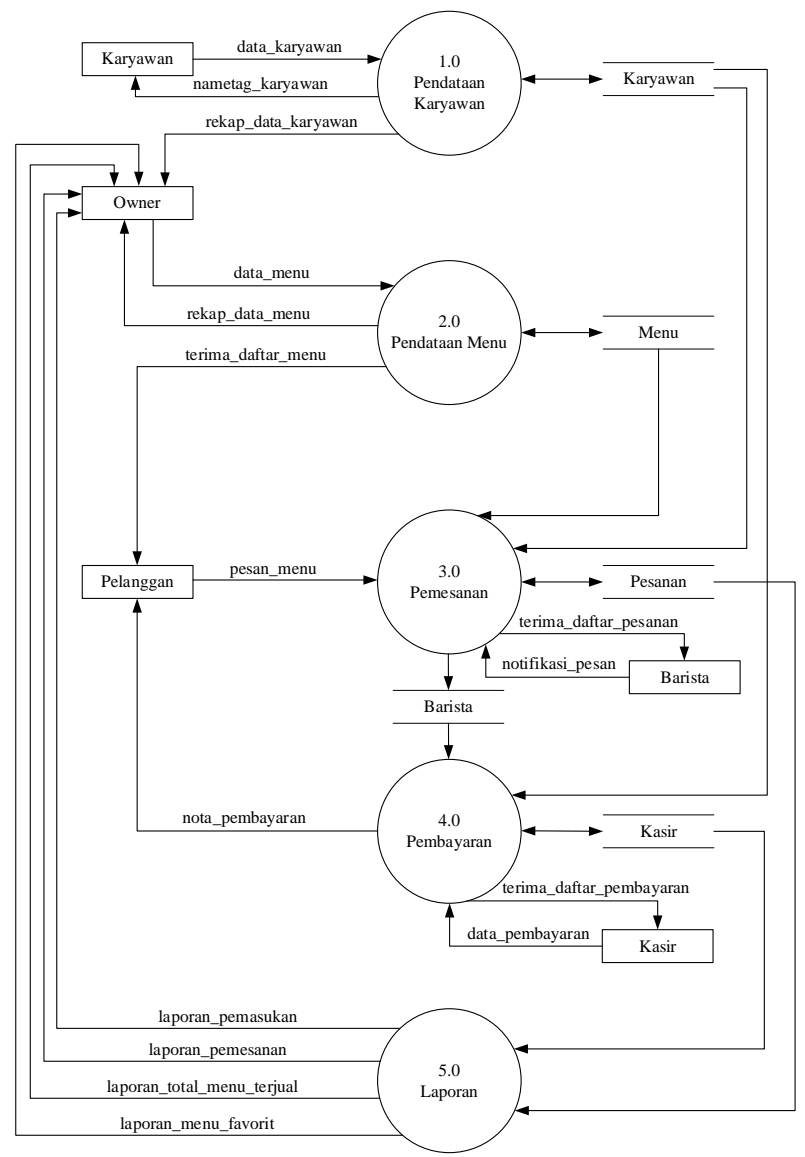

Gambar 2. Diagram Nol 


\section{Entity Relationship Diagram}
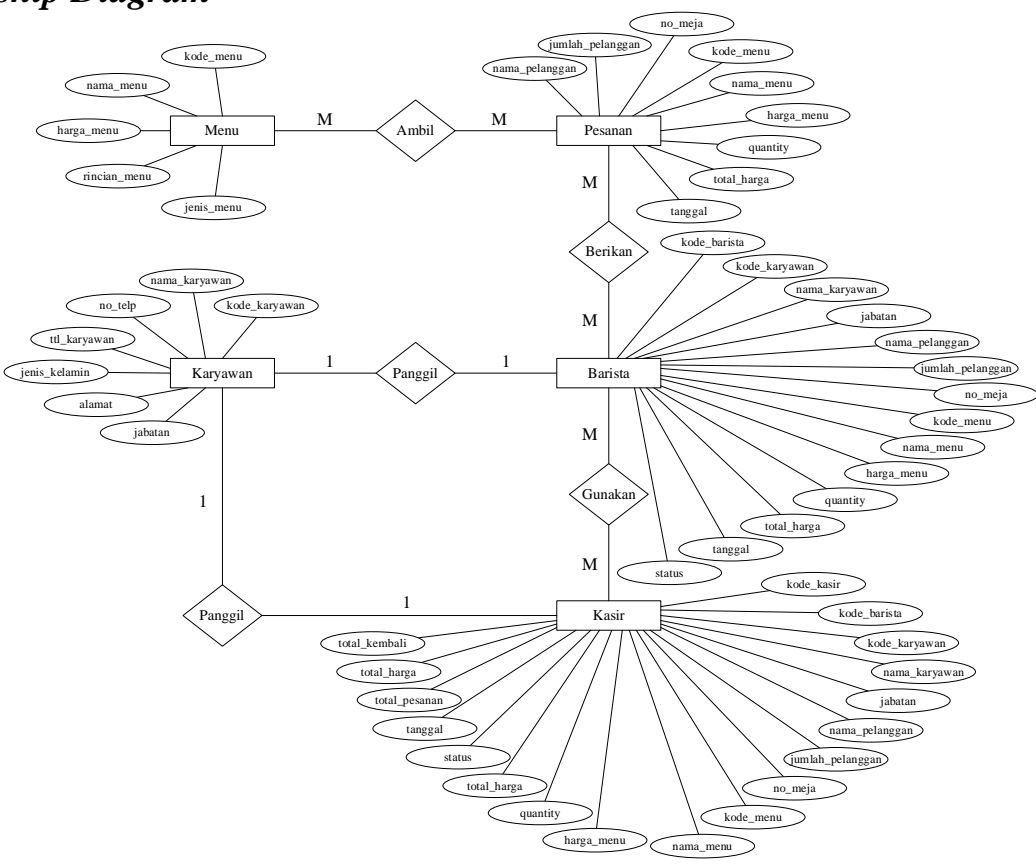

Gambar 3. Entity Relationship Diagram

\section{Tampilan Layar}

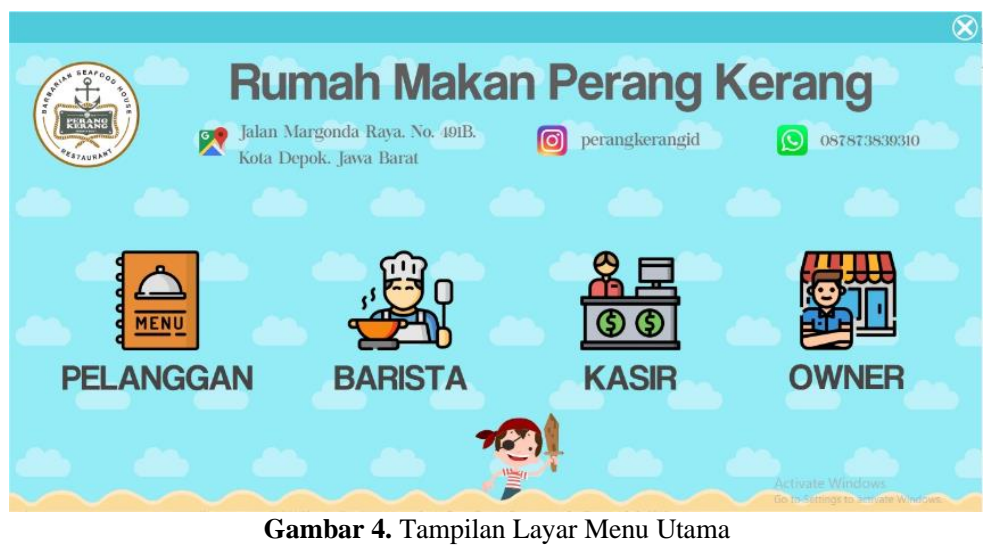

Tampilan Layar Menu Utama ini digunakan user akan menggunakan sistem sesuai posisi saat di RM Perang Kerang. Jika Pelanggan, maka akan masuk kedalam tampilan menu pelanggan untuk memesan menu, jika Barista, maka akan masuk kedalam tampilan data barista, jika Kasir, maka akan masuk kedalam tampilan data kasir, dan jika Owner, maka akan masuk kedalam tampilan menu utama owner.

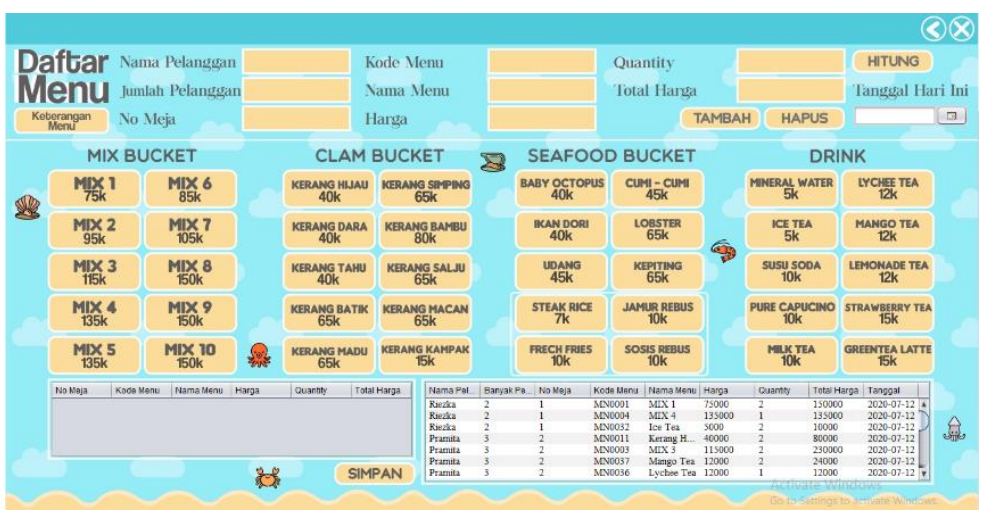

Gambar 5. Tampilan Layar Menu Pesanan Pelanggan 
Tampilan Layar Menu Pesanan Pelanggan ini digunakan saat pelanggan ingin memesan menu. Pelanggan harus memasukkan nama, jumlah pelanggan, nomor meja, lalu memilih menu dan akan tampil keterangan kode menu, nama menu, dan harga. Setelah itu, mengisi quantity lalu akan muncul total harga.

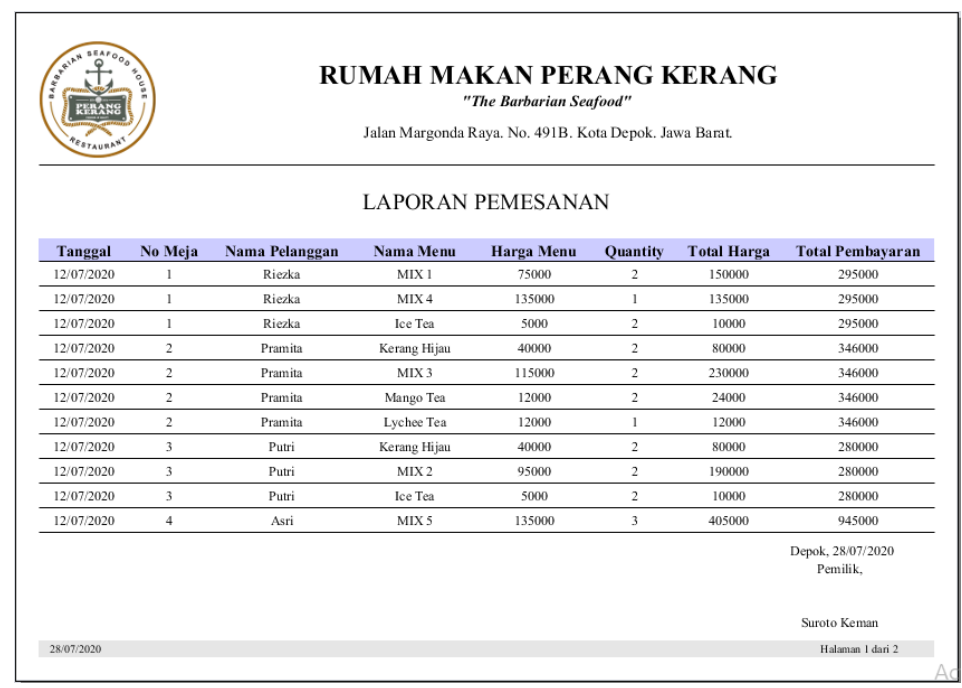

Gambar 6. Tampilan Form Keluaran Laporan Pemesanan

Tampilan Form Keluaran Laporan Pemesanan ini dapat dicetak oleh owner. Owner dapat memasukkan tanggal yang diinginkan, lalu mecetak dan mendapatkan hasil keluaran berupa tanggal, no meja, nama pelanggan, nama menu, harga menu, quantity, total harga, dan total pembayaran.

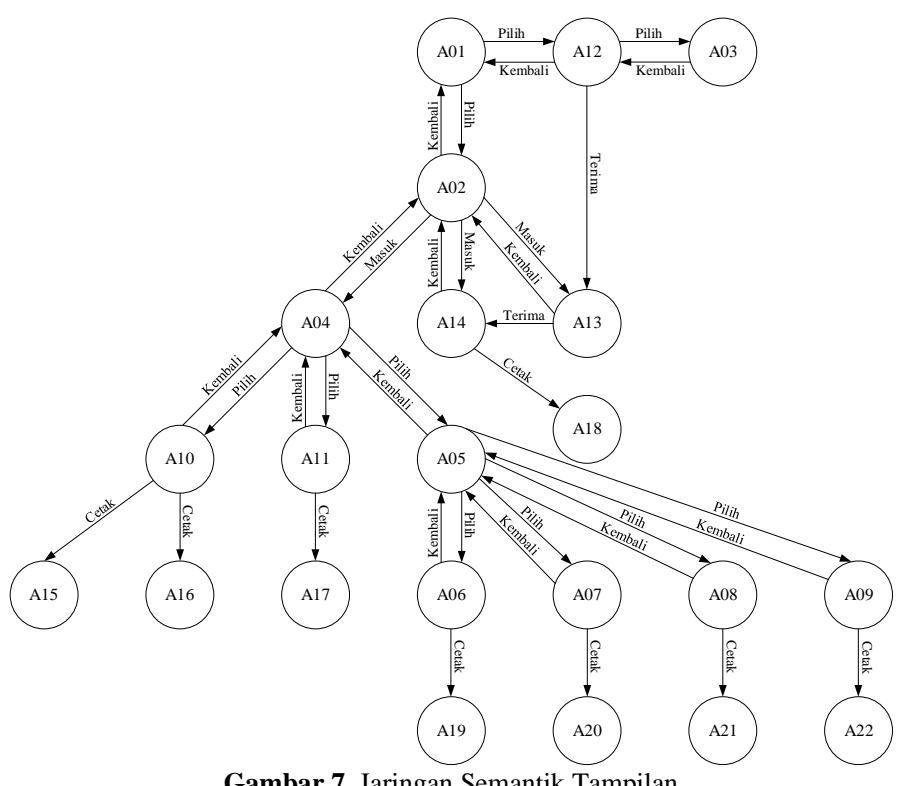

Gambar 7. Jaringan Semantik Tampilan

Keterangan pada gambar Jaringan Semantik Tampilan :

A01 : Tampilan Layar Menu Utama

A02 : Tampilan Layar Login

A03 : Tampilan Layar Keterangan Menu Pesanan

A04 : Tampilan Layar Menu Owner

A05 : Tampilan Layar Menu Laporan

A06 : Tampilan Layar Menu Laporan Pemasukan

A07 : Tampilan Layar Menu Laporan Pemesanan

A08 : Tampilan Layar Menu Laporan Total Menu Terjual

A09 : Tampilan Layar Menu Laporan Menu Favorit

A10 : Tampilan Form Masukan Data Karyawan

A11 : Tampilan Form Masukan Data Menu 
A12 : Tampilan Form Masukan Data Pesanan Pelanggan

A13 : Tampilan Form Masukan Data Barista

A14 : Tampilan Form Masukan Data Kasir

A15 : Tampilan Form Keluaran Rekap Data Karyawan

A16 : Tampilan Form Keluaran Nametag Karyawam

A17 : Tampilan Form Keluaran Rekap Data Menu

A18 : Tampilan Form Keluaran Nota Pembayaran

A19 : Tampilan Form Keluaran Laporan Pemasukan

A20 : Tampilan Form Keluaran Laporan Pemesanan

A21 : Tampilan Form Keluaran Laporan Total Menu Terjual

A22 : Tampilan Form Keluaran Laporan Menu Favorit

\section{SIMPULAN}

Berdasarkan hasil penelitian yang dilakukan oleh peneliti yang berjudul "Sistem Informasi Penjualan Berkonsep Pemesanan Mandiri RM Perang Kerang", maka diambil beberapa simpulan sebagai berikut :

1. Sistem Informasi Penjualan Berkonsep Pemesanan Mandiri RM Perang Kerang dibuat dengan menggunakan metode Research \& Development dengan bahasa pemrograman Java, yang disimpan dalam sebuah database MySQL sehingga dalam pengolahan data dan informasi akan tersimpan secara akurat, tepat, dan terkomputerisasi.

2. Dengan dibuatnya Sistem Informasi Penjualan Berkonsep Pemesanan Mandiri RM Perang Kerang, dapat mempermudah pelanggan untuk memesan menu, barista untuk melihat pesanan, kasir untuk melihat total pembayaran pesanan, dan pemilik dalam menjalankan sesuai kebutuhan yang ada pada RM Perang Kerang secara efektif dan efisien.

3. Dengan dibuatnya Sistem Informasi Penjualan Berkonsep Pemesanan Mandiri RM Perang Kerang, memudahkan pemilim untuk mencetak laporan pemasukan, laporan pemesanan, laporan total menu terjual, dan laporan menu favorit yang ada di RM Perang Kerang secara efisien dan tepat waktu.

\section{DAFTAR PUSTAKA}

Asropudin. P. (2013). Kamus Teknologi Informasi Komunikasi. Titian Ilmu.

Aswari, A., Santos Butar-Butar, F. T., \& Halimatusha'diah, H. (2020). Rancangan Aplikasi Elektronik Menu Restoran PJ83 Jakarta Berbasis Android. Jurnal Riset Dan Aplikasi Mahasiswa Informatika (JRAMI), 1(02), 222-229.

Indrajani, S. K. M. M. (2015). Database Design. Elex Media Komputindo.

Miftakhul Huda, B. K. (2010). Membuat Aplikasi Database. Elex Media Komputindo.

Riestiana, M., \& Sukadi. (2014). Sistem Informasi Penggajian Karyawan Pada Commenditaire Vennontschap (CV) RGL Bordir Dan Konveksi Pacitan. IJNS - Indonesian Journal on Networking and Security, 9330(4), 1-7.

Siahaan, I. K. (2018). Informasi Pemesanan Menu Dengan Perangkat Nirkabel Pada Cafe Resto. Jurnal Manajemen Sistem Informasi, 3(2), 1020-1029.

Sugiyono, P. (2011). Metodologi penelitian kuantitatif kualitatif dan R\&D. Alpabeta, Bandung.

Sulistiyowati, L. (2013). Panduan Praktis Memahami Laporan Keuangan. Elex Media Komputindo.

Sutabri, T. (2012). Konsep Sistem Informasi. Penerbit Andi.

Tegar., Purwanti, E., dan Purbandini. (2012). Analisis dan Perancangan Sistem Informasi Pemesanan dan Penjualan Barang Dengan Metode Berorientasi Objek di U.D Aneka Jaya Surabaya. Jurnal Sistem Informasi Universita Airlangga.

Tompoh, J. F., Sentinuwo, S. R., \& Sinsuw, A. A. E. (2016). Rancang Bangun Aplikasi Pemesanan Menu Makanan Restoran Berbasis Android. Jurnal Teknik Informatika, 9(1), 1-9.

Wardana, S. H. M. S. (2010). Menjadi Master PHP dengan Framework Codeigniter. Elex Media Komputindo. 